\title{
Bacterian Species Identification from Raw Cow Milk Sample - A Case Study
}

Camelia TULCAN ${ }^{1}$, Amandine HORCHOLLE $^{1}$, Simona MARC ${ }^{1}$, Jelena SAVICI, Călin MIRCU ${ }^{1}$, Ioan HUȚU ${ }^{1}$, Sorina POPESCU ${ }^{2}$, Oana-Maria BOLDURA ${ }^{1 *}$

\author{
${ }^{1}$ Faculty of Veterinary Medicine, Banat's University of Agricultural Sciences and Veterinary Medicine \\ "King Michael I of Romania",Timisoara, Str. Calea Aradului, 119, Romania \\ ${ }^{2}$ Faculty of Horticulture and Forestry, Banat's University of Agricultural Sciences and Veterinary \\ Medicine"King Michael I of Romania" Timisoara, Str. Calea Aradului, 119, Romania \\ * corresponding author: oanaboldura@usab-tm.ro
}

Bulletin UASVM Veterinary Medicine 77(1)/2020

Print ISSN 1843-5270; Electronic ISSN 1843-5378

doi:10.15835/buasvmcn-vm: 2019.0030

\begin{abstract}
The raw milk can supporta wide variety of microbiota, due to its high nutritional content. These microorganisms become from a variety of sources and in farm animals and can cause serious damage by infecting the mammary glands and causing mastitis. The mastitic milk is an important source of disease among the consumers. In this paper, we present a study case of pathogenic bacteria identification by DNA based methods from raw milk samples which were collected from farm cows with severe recurrent mastitis. Previously it was diagnosticated that multidrug resistant bacteria E. coli strains are causing those infections. The laboratory procedure consisted of isolation of DNA from raw cow milk samples, followed by PCR based bacterial identification and DNA sequencing. Data collected from sequencing experiment were aligned against reference sequences from bacterial strains. In our study it was found that Pseudomonas aeruginosa, is present in the mastitic milk samples.
\end{abstract}

Keywords: pathogenic bacteria, mastitis, DNA based methods, Pseudomonas spp.

\section{Introduction}

The pathogenic bacteria which populate cattle farms represent a danger because of their ability to disseminate and contaminate the environment. Fighting these bacteria is done by using multiple and unselective antibiotic treatment but most of the time, they are used as a prophylactic treatment which is one of the reasons why antibiotic-resistant bacteria are now a real scourge of our days.

Modern principles and practices in intensive farming systems (Borozan et al., 2013) often include usage of different additives in feedstuffs for the food-producing animals. Therefore, we are facing now increased bacterial virulence and, consequently, a high rate of treatment failures and large economic losses (Olarinmoye et al., 2013).
The presence of pathogenic bacteria in milk is the most important economic problem of dairy products industry (Hogeveen, 2005). Although the disease caused by these bacteria is generally called mastitis, it can be induced by several infectious agents, so far more than 150 species and bacterial subspecies in cattle are known, hence only 10 groups are identified in $95 \%$ of cases (Shome et al., 2011). These groups have been identified after a conventional classification that begins to be abandoned with the application of modern molecular epidemiological tools that have counteracted the old classification. Data have shown that within the same species some isolates can be classified as contagious and others as environmental, some as highly pathogenic and 
others less pathogenic, some cause severe clinical mastitis, others mild subclinical mastitis (Zadoks et al., 2011).

The diagnosis of clinical mastitis consists in the summary examination of milk, and is based on observing some changes in its normal appearance as well as by the presence of pus or blood clots.

About $40 \%$ of mastitis cases are known to develop into subclinical and chronic mastitis after antibiotic treatment has failed and the large part of recurrent infections are often caused by biofilm formation of bacteria such as Pseudomonas spp. (Hillerton and Kliem, 2002). The formed biofilm will survive the action of antibiotics and will, most often, result in recurrent infection.

In the case of the diagnosis of subclinical infection some issues may appear, because the milk has a normal appearance, but an increased number of somatic cells. Diagnosis of subclinical mastitis can be done in a variety of ways, including direct measurement of somatic cell level (SCC) or indirectly by conducting a California Mastitis Test (CMT), an electrical conductivity test or detecting enzymes present in tissue lesions such as LDH and NAG (Tatay-Dualde et al., 2015).

Those tests will usually identify the presence of mastitis pathogens, but will not provide a measure of the degree of inflammation associated with the infection. Individual cow SCCs will provide a determination of the level of infection in the herd of animals; therefore, for an accurate diagnosis those techniques must be combined with a microbiological culture. Only in this way, an inventory of the pathogenic effects of mastitis, an image of their distribution and an indication of the importance of the pathogen can be achieved.

But an ideal diagnostic test must be sensitive, specific, rapid, repeatable and economical. In most laboratories the classical method, which involves isolation and cultivation, is considered The Gold Standard for the diagnosis of mastitis.

However, this gold standard tends to be replaced by the modern molecular biological tools but still this is remaining in the debate because both of the methods have their strengths and weaknesses (Amr El-Sayed et al., 2017).

Lately, different DNA-based identification tests have become available with the characterization of pathogens at different phylogenetic levels depending on the purpose of the test. However, it should be noted that DNA-based screening can detect non-viable and / or inactive pathogens as opposed to tests that target less stable mRNA and therefore can detect only viable pathogens (Boor, 2004).

On the other hand, it is also possible to detect genes that code for possible antibiotic resistance, which may become even more accurate when using RNA-based gene expression studies (Mahmmod et al., 2015). In the last decades, several methods for tracking bacterial sources have been developed for deciphering the relationships between bacterial strains from different sources by comparing DNA fingerprinting data (Dundas et al., 2001; Brocchi et al., 2006).

In this study, the PCR sequencing method was used to amplify a bacterial specific DNA region that is to be sequenced. This procedure is followed by in silico analysis of the DNA sequence which has as result the identification of the bacteria that were initially present in the biological sample. Also here is described a protocol of isolating the DNA from the raw milk sample for DNA based screening by skipping the conventional microbiological culture.

\section{Materials and methods}

The biological material was represented by four samples of raw cow milk from different farms located in Arad County and they were noted with letter from A to D, from animals with a history of recurrent mastitis and resistance to drug treatment. In the case of the four animals the mastitis caused by the pathogen E. coli was communicated by the owner.

DNA extraction and purification: A preparatory stage of the samples was necessary and for that, $30 \mathrm{~mL}$ of each milk samples were centrifuged during 20 minutes at $14.000 \mathrm{rpm}$. Then, after the discarding of the supernatant the sediment was rinced in $300 \mathrm{~mL}$ Phosphate Buffered Saline (PBS) solution and centrifuged with the same centrifugation parameters. This step was repeated 3 times in the goal to finally obtain pure bacterial cells in the sample that represented the biological matrix for DNA isolation.

The extraction of the DNA from the five raw cow milk samples were performed with the innuPREP DNA Mini Kit (Analytik Jena, Germany), according with the manufacturer instructions.

DNA quantification and quality assessment: The measurements of the quality and quantity of the extracted and purified DNA were realized by 
spectrophotometry UV-Visible with the Nanodrop 8.000 spectrophotometer.

PCR and Electrophoresis: The PCR reactions of the bacterial DNA were performed with the Surecycler Agilent Technologies Thermocouple and the primers used were selected from the literature (Woo et al., 2008, James, 2010) and synthesized by Eurogentec in Belgium:

\section{F: 5' AGAGTTTGATCCTGGCTCAG 3' U1492R: 5' GGTTACCTTGTTACGACTT 3'}

The amplification mixture was prepared for a final volume of $50 \mu \mathrm{L}$ with $25 \mu \mathrm{L}$ of enzymes solution from the PCR Kit KapaRobust Hot Start 2X (KapaBiosystems, USA), $2 \mu \mathrm{L}$ of each primers (20 $\mu \mathrm{mol}), 2 \mu \mathrm{L}$ of DNA samples and $21 \mu \mathrm{L}$ of ultrapure water. The PCR program used was as follow: 3 minutes at $95^{\circ} \mathrm{C}$ for the initial denaturation, 20 seconds at $95^{\circ} \mathrm{C}$ for the denaturation, 20 seconds at $55-60^{\circ} \mathrm{C}$ for the primers hybridisationtion, 60 seconds at $72^{\circ} \mathrm{C}$ for the elongation and 3 minutes at $72^{\circ} \mathrm{C}$ for the final elongation (Dos Santos et al., 2019).

The electrophoresis was carried out by the migration during 40 minutes at $100 \mathrm{~V}$ of $25 \mu \mathrm{L}$ of each DNA PCR samples on an agarose gel at $1.8 \%$ in TAE buffer and then the observation of the migration was done under UV light with the transilluminator UVP GelDoc-It Imaging System (UVP, England).

Purification of PCR amplicons fragments from agarose gel: The extraction from the agarose gel was realized with the Monarch DNA Gel Extraction Kit (New England BioLabs, USA), and prepared for the sequencing protocol (Bozac et al., 2016).

DNA sequencing: The PCR fragments extracted from the agarose gel were sequenced at the Macrogen Laboratory in Amsterdam, Netherlands. The DNA sequences obtained were compared by BLAST to all the bacteria strains sequences in the international database GenBank, NCBI, USA.

\section{Results and discussions}

As previously stated by A. El-Sayed et al. (2017) the preliminary and very important step in a DNA based method of mastitis diagnosis is represented by the DNA extraction procedure. It is in this step were the entire quality and accuracy of the test is somehow assured. This is why new methods, kits, lysis buffers and pre-enzymatic treatments of the milk sample are always developed (Dibbern et al., 2015; Pokorska et al., 2016). Most of these methods are implying increased analysis costs for independent laboratories because of their specificity for milk samples. Considering this, one of our objective was to adapt and develop a new sample preparation protocol that has enable us to start the analysis from a small amount of raw sample (either fresh, refrigerated or frozen) and also obtaining the most of genetical material without using the time consuming conventional bacterial culture. This sample preparation protocol is described in the Material and Methods section and is, compared with the bibliographic data, most economic and time consuming efficient. The DNA extraction protocol that is to be followed can be adapted to any user preferred method, since the biological matrix is represented by cleaned milk somatic cells. In order to sustain our statement recordings of DNA quality and quantity were performed and overall our results are slightly better than those that were available in the literature (Pokorska et al., 2016).

The DNA quality and quantity after the extraction and after the purification of the bacterial DNA were measured by UV-VIS spectrophotometry (Tab. $1)$. For the extraction results of the ratio A260/ A280, the values were all under 1.8 meaning that the sample were not entirely pure however, this is to be expected when the biological matrices have a high proteins and carbohydrates content. This is why it is recommended, in order to assure the best PCR results, to add an additional purification step to the isolating protocol. As it is shown in Table1, the values of the purification results of the ratio A260/A280 were all around 1.8 meaning that the samples were pure and by extension most pure than before the purification process.

The first molecular analysis were performed in order to confirm the presence of the infectious agent E.coli and also some antibiotic resistant genes were detected by performing End-Point PCR analysis (data not shown). However, this represented only a confirmation of the previous diagnostic and the adapted treatment disposed accordingly did not provide the expected results. Since the E.coli infection was counteracted by antibiotics treatment, it was clearly that some other infection causing agent may be present in the samples. Therefore, instead of searching for 
Table. 1. Results for DNA quality and quantity by UV-VIS spectrophotometry

\begin{tabular}{ccccccc}
\hline & \multicolumn{3}{c}{ Extraction results } & \multicolumn{3}{c}{ Purification results } \\
\hline Sample & $\begin{array}{c}\text { Concentration } \\
(\mathrm{ng} / \mu \mathrm{L})\end{array}$ & $\begin{array}{c}\text { A260/ } \\
\text { A280 }\end{array}$ & A260/A230 & $\begin{array}{c}\text { Concentration } \\
(\mathrm{ng} / \mu \mathrm{L})\end{array}$ & A260/A280 & $\begin{array}{c}\text { A260/ } \\
\text { A230 }\end{array}$ \\
\hline A & 36,78 & 1,28 & 0,67 & 74,30 & 1,65 & 1,73 \\
\hline B & 42,04 & 1,12 & 0,62 & 89,40 & 1,58 & 1,82 \\
\hline C & 48,56 & 1,09 & 0,74 & 96,03 & 1,71 & 1,65 \\
\hline D & 38,90 & 1,10 & 0,91 & 78,20 & 1,64 & 1,85 \\
\hline
\end{tabular}

Note: A - Absorbance; A260/A280 and A260/A230 - Absorbances Ratios.

them, it was decided that the most effective and accurate test is PCR sequencing based.

According to a large number of studies carried for in the last two decades (Shinichi et al., 2019; Lima et al., 2018) the 16S rRNA genes are the most used DNA sequences that are used for identification of bacterial species and subspecies. Since there are a large number of sequences that can be found in Data Bases and the protocols being already standardized this method was preferred for the identification of secondary infectious agents that were suspected to be present in the biological samples.

After performing the PCR using the specific primers an amplicon of approximately $900 \mathrm{pb}$ was obtained (Figure 1). Some faint non-specific PCR product could be observed, but since the amplicon of interest was isolated directly from the agarose gel this was pure and those unspecific amplicons did not interfered with the final result.
The DNA samples were sequenced and the results returned sequences over $1 \mathrm{~kb}$ for each of the analyzed samples. The resulted DNA sequences (Figure 2) were aligned in the NCBI Database and compared using the BLAST function of the same Database (Figure 3) with the bacterial strains sequences stored in GenBank International Database. The BLAST has shown several significant sequences alignments (Figure 3 ) between the DNA sequences of the samples and DNA sequences of others bacterial strains of the database.

The most significant matches were with the microorganism Pseudomonas aeruginosa. In total we were able to identify several matches at $88 \%$ and $87 \%$ identity with bacterial DNA sequences of Pseudomonas aeruginosa strains such as the Pseudomonas aeruginosa strain DSM 50071 16S ribosomal RNA gene (Figure 4).

The obtained result was somehow unexpected since it is stated that Pseudomonas aeruginosa, is

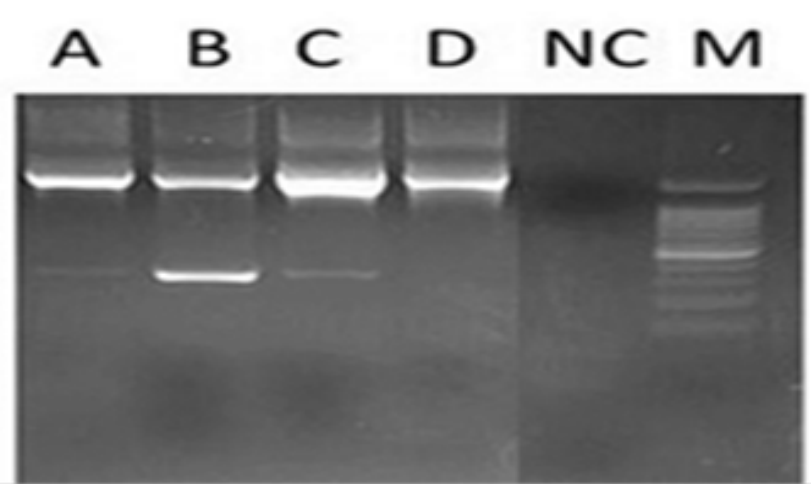

Figure 1. Electrophoresis agarose gel of the PCR DNA fragments of 16S rRNA genes from the four raw cow milk samples. A- DNA isolated from the sample A; B- DNA isolated from the sample B; C- DNA isolated from the sample C; D- DNA isolated from the sample D; NC- Negative reaction Control and M- Molecular weight marker (PCRSizer 100pb DNA Ladder, Norgen, Canada) 


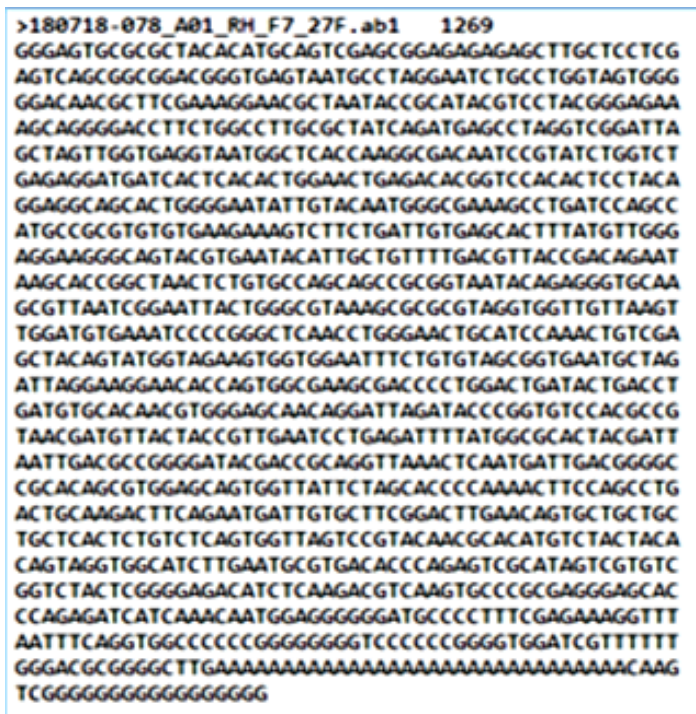

Figure 2. Example of DNA sequence obtained after DNA amplicon sequencing.

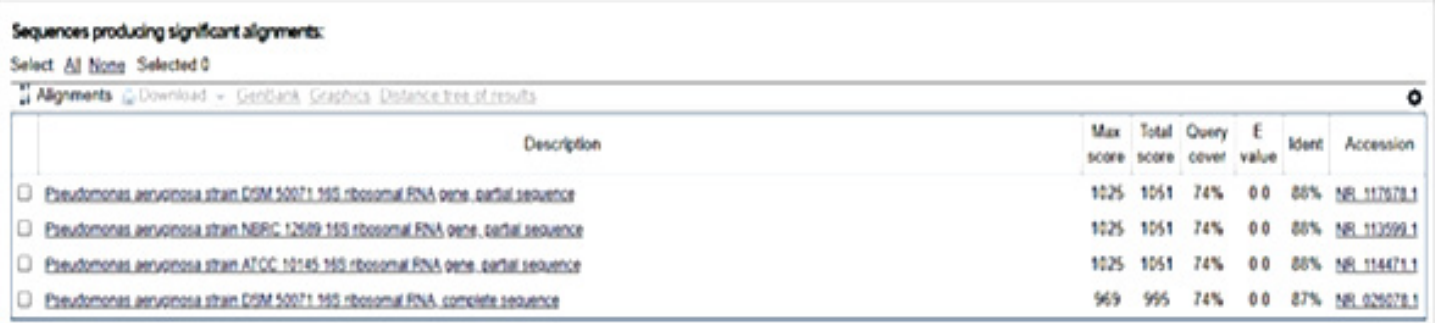

Figure 3. Sequences of $16 \mathrm{~S}$ ribosomal RNA gene producing significant alignments.

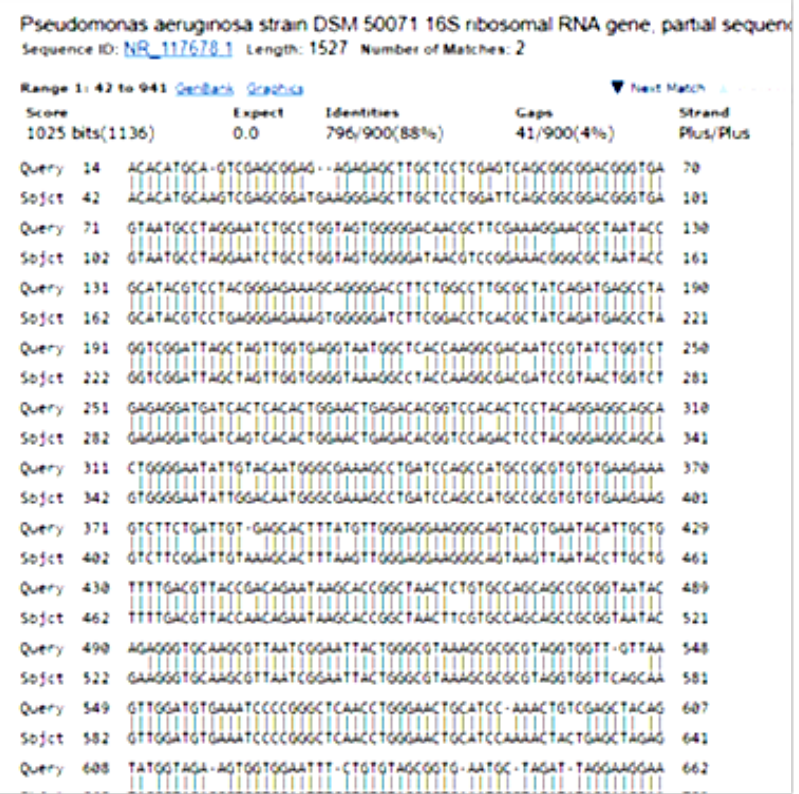

Figure 4. Partial sequence of the alignment of the biological sample (Query) and Pseudomonas aeruginosa strain DSM 50071 16S ribosomal RNA reference gene (Sbjct). 
reported in only 1 to $3 \%$ of mastitis cases reported worldwide (Ohnishi et al., 2011; Park et al., 2014 ). However it is worth mentioning that in each of the four analyzed samples were found to containing others infectious agents, known to cause bovine mastitis. Also, more important, the milk samples were collected from animals belonging to an acclimatized imported bovine breed that can be sensitive to this bacterial strain. However, we did not find any records to sustain our suppositions and more clarifying studies are to be made in this direction.

\section{Conclusion}

The protocol for isolating DNA directly from bovine milk, described in this paper proved to be of high performance in terms of reducing the time and economical costs of analysis, providing very good outcomes.

The PCR and sequencing of the DNA and sequences of the four samples from raw cow milk from cows with mastitis in this study revealed the presence of pathogenic Pseudomonas aeruginosa bacteria strains, that were not identified previously, using the molecular marker-based identification method that proved to be efficient and precise and but also unexpected.

Therefore, we conclude that further conventional methods must be applied in order to effectively diagnose the source of mastitis for those four animals. This confirmation will be followed by a validation of the diagnose method that being of great help for clinical veterinarians.

Acknowledgments. This work has been supported by the project PN-III-P1-1.2-PCCDI-2017-0361, Abordarea bioeconomică a agenților antimicrobieni - utilizare și rezistență.

\section{References}

1. Biggs A (2009). Mastitis in cattle. Crowood Press, Marlborough, UK.

2. Boor K (2004). Molecular methods in food safety. In Zadoks (Eds.), Molecular methods in Milk quality. Proceedings of a symposium to celebrate the opening of the new Ithaca facilities of quality milk production services.

3. Borozan A, Bordean D, Boldura OM, Parvulescu L, Horablaga M, Cojocariu L (2013). Actinobacteria source of information on soil quality. SGEM Conference Proceedings, 489-496.

4. Bozac P, Popescu S, Botau D, Boldura OM, Pirvulescu $P$ (2016). Molecular Characterization for some new
Fusarium Isolates Collected from the West Part of Romania, Romanian Biotechnological Letters, 21: 3.

5. Brocchi M, Ferreira A, Lancellotti M, Stehling EG,. Campos TA, Nakazato G, Castro AF, Silveira WD (2006). Typing of avian pathogenic Escherichia coli strains by REP-PCR, Pesq. Vet. Bras., 26 (2): 299-311.

6. Dibbern A, Botaro B, Viziack M, Silva L, Santos M (2015). Evaluation of methods of DNA extraction from Staphylococcus aureus in milk for use in real-time PCR, J Gen and Mol Res, 14:227-33.

7. Dos Santos H, Argolo CS, Argôlo-Filho R C, Loguercio LL (2019). A 16S rDNA PCR-based theoretical to actual delta approach on culturable mock communities revealed severe losses of diversity information, BMC Microbiology, Doi:10.1186/s12866-019-1446-2.

8. Dundas S, Todd WT Stewart AI, Murdoch PS, Chaudhuri AK, Hutchinson SJ (2001). The central Scotland Escherichia coli 0157: H7 outbreak: Risk factors for the haemolytic uremic syndrome and death among hospitalized patients, Clin. Infect. Dis. 33: 923-931.

9. El-Sayed A, Awad W, Abdou NE., Castañeda Vázquez $\mathrm{H}$ (2017). Molecular biological tools applied for identification of mastitis causing pathogens. International Journal of Veterinary Science and Medicine, Doi: 10.1016/j.ijvsm.2017.08.002.

10. Ghorbanpoor M, Seyfiabad-Shapouri M, Moatamedi H, Jamshidian M, Gooraninejad S (2007). Comparison of PCR and bacterial culture methods for diagnosis of dairy cattle's subclinical mastitis caused by Staphylococcus aureus, J Vet Res, 62:87-91.

11. Hillerton JE, Kliem KE (2002). Effective treatment of Streptococcus uberis clinical mastitis to minimize the use of antibiotics, J. Dairy Sci, 85:1009-1014.

12. Hogeveen $H$ (2005). Mastitis is an economic problem. Proceedings of the British Mastitis Conference, Institute for Animal Health/The Dairy Group/ADAS Stoneleigh, UK, $1-13$.

13. James GS (2010). Universal bacterial identification by PCR and DNA sequencing of $16 \mathrm{~S}$ rRNA gene. In M. Schuller, T. P. Sloots, C. L. Holliday, G. S. James, \& I. W. J. Carter (Eds.), PCR for Clinical Microbiology. Springer, New York.

14. Kai S, Matsuo Y, Nakagawa S, Kryukov K, Matsukawa S, Tanaka H, Iwai T, Imanishi T, Hirota K (2019). Rapid bacterial identification by direct PCR amplification of $16 \mathrm{~S}$ rRNA genes using the MinIONTM nanopore sequencer, FEBS Open Bio, Doi: 10.1002/2211-5463.12590

15. Lima SF, Bicalho MLS, Bicalho RC (2018). Evaluation of milk sample fractions for characterization of milk microbiota from healthy and clinical mastitis cows. PLoS ONE, Doi.org/10.1371/journal.pone.0193671

16. Mahmmod YS, Klaas IC, Katholm J, Lutton M, Zadoks RN (2015). Molecular epidemiology and strain-specific characteristics of Streptococcus agalactiae at the herd and cow level. J Dairy Sci, 98:13-24.

17. Ohnishi M, Sawada T, Hirose K, Sato R, Hayashimoto M, Hata E, Yonezawa C, Kato H (2011). Antimicrobial susceptibilities and bacteriological characteristics of bovine Pseudomonas aeruginosa and Serratia marcescens 
isolates from Mastitis. Vet Microbiol, Doi.org/10.1016/j. vetmic.2011.06.023

18. Park HR, Hong MK, Hwang SY, Park YK, Kwon KH, Yoon JW, Shin S, Kim JH, Park YH (2014). Characterisation of Pseudomonas aeruginosa related to bovine mastitis, Acta Vet Hung. Doi: 10.1556/AVet.2013.054.

19. Pokorska J, Kułaj D, Dusza M, Justyna Zychlinska-Buczek J, Makulska J (2016). New rapid method of DNA isolation from milk somatic cells, Anim Biotechnol, 27:113-7

20. Sears PM, González RN, Wilson DJ, Han HR (1993). Procedures for Mastitis Diagnosis and Control. Veterinary Clinics of North America, Food Animal Practice, Doi:10.1016/s0749-0720(15)30613-7.

21. Shome B, Das Mitra S, Bhuvana M, Krithiga N, Velu D, Shome R (2011). Multiplex PCR assay for species identification of bovine mastitis pathogens. J Appl Microb, 111:1349-56.
22. Tatay-Dualde J, Sánchez A, Prats-van der Ham M, GómezMartín A, Aterna A, Corrales J (2015). Sensitivity of two methods to detect Mycoplasma agalactiae in goat milk, Irish Vet J, 68:21-5.

23. Woo PCY, Lau SKP, Teng JLL, Tse H, Yuen KY (2008). Then and now: use of $16 \mathrm{~S}$ rDNA gene sequencing for bacterial identification and discovery of novel bacteria in clinical microbiology laboratories, Clinical Microbiology and Infection, 14, 10: 908-934.

24. Zadoks R, Middleton J, McDougall S, Katholm J, Schukken Y (2011). Molecular epidemiology of mastitis pathogens of dairy cattle and comparative relevance to humans. J Mammary Gland Biol Neoplasia 16:357-72. 